\title{
PENGKAJIAN PEMUPUKAN PADA USAHATANI JAGUNG DI LAHAN KERING DAN LAHAN SAWAH DI KABUPATEN PANDEGLANG BANTEN
}

\author{
Resmayeti Purba \\ Balai Pengkajian Teknologi Pertanian Banten \\ Jalan Raya Ciptayasa Km 01 Ciruas, Serang 42182 Banten \\ Email: resmayeti63@yahoo.com
}

\begin{abstract}
ABSTRAK
Hasil jagung di lahan sawah dan di lahan kering dapat ditingkatkan dengan pemberian pupuk yang tepat, baik dosis maupun jenisnya. Pengkajian ini bertujuan untuk mengetahui pengaruh pemupukan terhadap hasil jagung hibrida di lahan sawah dan lahan kering di Kabupaten Pandeglang, Banten. Pengkajian dilakukan pada lahan sawah dan lahan kering milik petani di Kec. Mandalawangi pada bulan Mei-Agustus 2016. Percobaan menggunakan Rancangan Acak kelompok, 3 perlakuan dan 8 ulangan. Perlakuan terdiri atas tiga pemupukan yaitu : P1 (pemupukan rekomendasi KATAM : Urea $325 \mathrm{~kg} / \mathrm{ha}+75 \mathrm{~kg} / \mathrm{ha} \mathrm{SP}-36+80 \mathrm{~kg} / \mathrm{ha} \mathrm{KCl}+$ pupuk kandang 2 ton/ha); P2 (pemupukan rekomendasi Balitsereal jagung hibrida : Urea $250 \mathrm{~kg} / \mathrm{ha}+300 \mathrm{~kg}$ NPK Phonska + pupuk kandang 2 ton/ha) dan P3 (pemupukan cara petani : Urea $100 \mathrm{~kg} / \mathrm{ha}$ + NPK Phonska $200 \mathrm{~kg} / \mathrm{ha}$ ). Hasil kajian menunjukkan bahwa hasil biji jagung tertinggi di lahan sawah sebesar 6,25 t/ha dan lahan kering sebesar 5,78 t/ha ditemukan pada pemupukan P1 (rekomendasi Balitsereal, yaitu : Urea $250 \mathrm{~kg} / \mathrm{ha}$ + $300 \mathrm{~kg} / \mathrm{ha}$ NPK Phonska. Jagung hibrida varietas Bima dapat dikembangkan di lahan kering dan di lahan sawah dengan pemberian pupuk Urea $250 \mathrm{~kg} / \mathrm{ha}+300 \mathrm{~kg} / \mathrm{ha}$ NPK Phonska + pupuk organik 2 ton/ha.
\end{abstract}

Kata kunci : pemupukan, jagung, hasil

\begin{abstract}
The yield of maize in paddy fields and on dry land can be increased by appropriate fertilizer, both dosage and type. This study aims to determine the effect of fertilization on the yield of hybrid corn in paddy field and dry land in Pandeglang, Banten. The assessment was conducted on farmers' fields and dry land in Kec. Mandalawangi in May-August 2016. Experiments using Randomized Block Design, 3 treatments and 8 replications. The treatment consisted of three fertilizers: P1 (KATAM Urea $325 \mathrm{~kg} / \mathrm{ha}+75 \mathrm{~kg} / \mathrm{ha} \mathrm{SP-36}+\mathrm{KCl} 80 \mathrm{~kg} / \mathrm{ha}+2$ tons / ha manure); P2 (fertilizer recommendation of Balitsereal hybrid corn: Urea $250 \mathrm{~kg} / \mathrm{ha}+300 \mathrm{~kg}$ NPK Phonska + manure 2 ton / ha) and P3 (fertilizer farming method (Urea $100 \mathrm{~kg} / \mathrm{ha}+$ NPK Phonska $200 \mathrm{~kg} / \mathrm{ha}$ ). The results showed that the highest yield of maize seeds in paddy fields was $6.25 \mathrm{t} / \mathrm{ha}$ and dry land of $5.78 \mathrm{t} / \mathrm{ha}$ was found in fertilization based on Balitsereal recommendation: Urea $250 \mathrm{~kg} / \mathrm{ha}+300$ $\mathrm{kg} / \mathrm{ha}$ NPK Phonska. Hybrid maize varieties of Bima can be developed in dry land and in paddy fields with Urea fertilizer $250 \mathrm{~kg} / \mathrm{ha}+300 \mathrm{~kg} / \mathrm{ha} N P K$ Phonska+organic fertilizer 2 ton / ha.
\end{abstract}

Keywords : fertilization, corn, yield

\section{PENDAHULUAN}

Jagung merupakan salah satu komoditas unggulan penting pada Kementerian Pertanian. Produksi jagung dalam negeri diharapkan mampu memenuhi kebutuhan pakan dan pangan yang setiap tahun terus meningkat. Kebutuhan jagung untuk bahan baku industri pakan meningkat $10-15 \%$ sehingga produksi jagung yang cukup dan berkelanjutan berperan strategis dalam menunjang kinerja pabrik pakan ternak. Pada tahun 2014 luas panen jagung di Provinsi Banten 3,152 ha, produktivitas 33,36 kw/ha dan produksi 10.514 tonn (BPS Banten 2015). Kabupaten Pandeglang dan Kabupaten Tangerang merupakan wilayah pengembangan jagung oleh pemerintah daerah Provinsi Banten dan pada tahun 2016 luas tanam mencapai 3.0005000 ha. Namun produktivitas di tingkat petani masih rendah, yaitu 3-4 t/ha. 
Pemenuhan produksi jagung melalui peningkatan produktivitas jagung dilakukan dengan perbaikan budidaya di tingkat petani dengan pemupukan yang tepat dosis dan jesnis serta berimbang. Peran teknologi, terutama teknologi pemupukan sangat nyata dalam peningkatan hasil jagung. Menurut Fadwiwati dan Tahir (2013) pemupukan merupakan faktor yang mempengaruhi usahatani jagung. Hasil kajian menunjukkan bahwa secara partial, varietas memberikan kontribusi sebesar $15 \%$ terhadap produksi, namun jika diintegrasikan bersama dengan pupuk, peningkatan hasil jagung dapat mencapai 30\% (Taufik dan Thamrin, 2009). Permasalahan teknis yang menjadi rendahnya produktivitas jagung antara lain, seringnya gangguan iklim, serangan hama dan penyakit, penggunaan benih yang kurang bermutu, pemupukan yang tidak berimbang (Susanto dan Sirappa, 2015). Sedangkan di Kabupaten Pandeglang penyebab rendahnya produktivitas jagung adalah penggunaan benih kurang bermutu dan adaptif serta pemupukan yang tidak berimbang.

Badan Penelitian dan Pengembangan Pertanian melalui Pusat Penelitian dan Pengembangan Tanaman Pangan dan Balai Penelitian Tanaman Serealia terus berusaha memperbaiki kelemahan varietas varietas unggul yang sudah ada dengan merakit varietas unggul baru yang berpotensi hasil lebih baik. Beberapa varietas jagung hibrida adalah : Bima 19, Bima 20 rata-rata potensi hasilnya 5-12 t/ha (Adnan et al., 2012). Hasil hasil penelitian di Lampung menunjukkan bahwa jagung dapat tumbuh dengan baik di lahan kering atau di lahan sawah (Rumbaina dan Mustikawati, 2007). Namun satu varietas yang unggul disuatu tempat belum tentu juga unggul dan adaptif di tempat yang lain.

Penggunaan pupuk berimbang merupakan salah satu komponen pengelolaan tanaman terpadu selain komponen lainnya. Pemakaian pupuk kimia secara intensif terutama pupuk N, P dan K serta penggunaan bahan organik yang terabaikan dalam upaya pencapaian hasil yang tinggi merupakan salah satu pemicu menurunnya produktivitas lahan. Pemupukan merupakan salah satu faktor yang dapat mempengaruhi pertumbuhan dan hasil jagung. Penambahan bahan organik ke dalam tanah sangat penting karena selain dapat meningkatkan kandungan $\mathrm{C}$ organik tanah, juga merupakan sumber hara. Pemupukan jagung di lahan sawah dan di lahan kering yang dapat diaplikasi oleh petani adalah pemupukan berdasarkan rekomendasi Balitsereal atau pemupukan jagung berdasarkan rekomendasi KATAM. Namun untuk memperoleh hasil jagung optimal perlu dikaji pemupukan spesifik lokasi yang sesuai bagi tanaman jagung di setiap wllayah. Hasil kajian dengan pemupukan berimbang memberikan hasil jagung optimal. Hasil jagung dapat ditingkatkan dengan pemupukan yang tepat baik dosis dan waktu maupun jenis pupuk yang diberikan. Hara N, P dan $\mathrm{K}$ merupakan hara makro yang sangat penting bagi pertumbuhan tanaman. Sumber hara N, P dan K dapat berasal dari pelapukan mineral tanah, bahan organik, air dan pemupukan. Pemupukan N dan pupuk kandang nyata meningkatkan pertumbuhan dan bobot biji jagung (Kasno dan Rostam, 2013). Pemberian pupuk yang tidak sesuai dengan kebutuhan tanaman baik jumlah maupun dosisnya menyebabkan rendahnya efisiensi pemupukan (Efendi et al., 2012) dan untuk memperoleh hasil jagung optimal perlu penerapan pemupukan rekomendasi spesifik lokasi (Fadwiwati dan Tahir, 2013).

Berdasarkan hasil-hasil penelitian tersebut dilakukan kajian yang bertujuan untuk mengetahui pengaruh pemupukan terhadap pertumbuhan hasil pipilan jagung pada lahan kering dan lahan sawah, di Kabupaten Pandeglang, Banten

\section{METODE PENELITIAN}

Kajian pemupukan dilakukan pada lahan sawah dan lahan keringdi desa Mandalawangi Kec. Mandalawangi Kabupaten Pandeglang, Banten. Kegiatan pengkajian berlangsung dari Mei sampai Agustus 2016. Lahan yang digunakan adalah milik petani dengan luas areal 5000m2. Lahan diolah secara sempurna, dibajak, digaru. Varietas jagung yang digunakan adalah jagung hibrida Bima

Rancangan pengkajian disusun dalam rancangan Acak Kelompok 3 perlakuan dengan 8 ulangan. Perlakuan pemupukan adalah (P1). $325 \mathrm{~kg} / \mathrm{ha}+75 \mathrm{~kg} / \mathrm{ha}$ SP-36/ha $+80 \mathrm{~kg} / \mathrm{ha} \mathrm{KCl}+2$ ton pupuk kandang/ha, (P2) $250 \mathrm{~kg} / \mathrm{ha}$ Urea $+300 \mathrm{~kg} / \mathrm{ha}$ NPK Phonska + pupuk kandang 2 ton/ha, (P3) 100 $\mathrm{kg} / \mathrm{ha}$ Urea $+200 \mathrm{~kg} / \mathrm{ha}$ NPK Phosnka dan tanpa pupuk kandang. Petak perlakuan berukuran $200 \mathrm{~m} 2$. Saluran antar perlakuan 
dibuat dengan prinsip untuk menghindari kontaminasi pupuk antar petak perlakuan. Pemberian pupuk organik pada lahan diberikan pada saat pengolahan tanah dengan cara disebar dan sebagai penutup lubang saat tanam jagung. Penanaman dilakukan dengan pembuatan lubang tanam dengan tugal sedalam $5 \mathrm{~cm}$, jarak tanam $70 \times 25 \mathrm{~cm}$, masukkan benih jagung dalam lubang 1-2 biji dan tutup dengan pupuk kandang. Menurut Muis et al., (2013) untuk mengendalikan penyakit bulai dilakukan perlakuan benih, 1 $\mathrm{kg}$ benih dicampur dengan $2 \mathrm{~g}$ Ridomil yang dilarutkan dalam 7,5-10 ml air dan untuk pengendalian penggerek dengan pemberian insektisida Furadan 3G melalui pucuk daun tanaman (3-4 butir/tanaman). Penyiangan pertama dilakukan pada umur 15 hari setelah tanam dan penyiangan kedua pada umur 20-30 hari.

Parameter yang diamati adalah : tinggi tanaman pada umur 30 HST, 60 HST dan 90 HST dan hasil pipilan jagung. Pengukuran tinggi tanaman dilakukan terhadap 10 tanaman contoh per petak perlakuan. Pengukuran tinggi tanaman jagung dilakukan dari permukaan tanah sampai ujung daun. Hasil pipilan jagung diukur dengan melakukan panen pada luasan ubinan $3 \mathrm{~m} \mathrm{x} \mathrm{2,75} \mathrm{cm}$ (4 baris x 11 tanaman) yang diambil dari tengah petak. Data ditabulasi dan selanjutnya dilakukan analisis staistik menggunakan program SAS dengan uji Duncan untuk mengetahui perbedaan antar perlakuan

\section{HASIL DAN PEMBAHASAN}

Tinggi Tanaman Jagung. Pertumbuhan tanaman jagung yang digambarkan oleh tinggi tanaman umur pada umur 30, 60 dan 90 HST dapat dilihat pada Tabel 1. Pengaruh pemupukan terlihat pada tinggi tanaman dan berbeda antar perlakuan. Hal ini diduga pupuk yang diberikan pada lahan sawah dan lahan kering memberikan respon positif terhadap pertumbuhan tanaman. Pada umur 90 HST terlihat bahwa dari ketiga perlakuan pemupukan, perlakuan P2, yaitu Urea 250 $\mathrm{kg} / \mathrm{ha}+300 \mathrm{~kg} / \mathrm{ha}$ NPK Phonska + pupuk organik 2 ton/ha memberikan tinggi tanaman jagung di lahan kering $(218 \mathrm{~cm}$.) dan di lahan sawah $(225 \mathrm{~cm})$ yang lebih tinggi dan berbeda nyata dengan perlakuan pemupukan P1 (Urea $325 \mathrm{~kg} / \mathrm{ha}+\mathrm{SP}-3675 \mathrm{~kg} / \mathrm{ha}+80 \mathrm{~kg} / \mathrm{ha} \mathrm{KCl}$ + pupuk organik 2 ton/ha di lahan kering (192 $\mathrm{cm})$ dan di lahan sawah $(201 \mathrm{~cm})$ sedangkan perlakuan pemupukan P3 Urea $100 \mathrm{~kg} / \mathrm{ha}$ dan NPK Phonska $200 \mathrm{~kg} / \mathrm{ha}+$ tanpa pupuk organik memberikan tinggi tanaman terendah, yaitu di lahan kering $(179 \mathrm{~cm})$ dan di lahan sawah $(188 \mathrm{~cm})$

Tabel 1.

Tinggi tanaman jagung pada umur 30, 60 dan 90 HST

\begin{tabular}{lllllll}
\hline Perlakuan & \multicolumn{3}{l}{ Lahan kering } & \multicolumn{3}{l}{ Lahan sawah } \\
\cline { 2 - 7 } & 30 & 60 & 90 & 30 & 60 & 90 \\
& HST & HST & HST & HST & HST & HST \\
\hline P1 & $68^{\mathrm{b}}$ & $170^{\mathrm{b}}$ & $192^{\mathrm{b}}$ & $69^{\mathrm{b}}$ & $175^{\mathrm{a}}$ & $201^{\mathrm{b}}$ \\
P2 & $75^{\mathrm{a}}$ & $189^{\mathrm{a}}$ & $218^{\mathrm{a}}$ & $78^{\mathrm{a}}$ & $197^{\mathrm{a}}$ & $225^{\mathrm{a}}$ \\
P3 & $60^{\mathrm{c}}$ & $151^{\mathrm{c}}$ & $179^{\mathrm{c}}$ & $64^{\mathrm{c}}$ & $161^{\mathrm{c}}$ & $188^{\mathrm{c}}$ \\
\hline
\end{tabular}

Hasil Jagung. Hasil pipilan jagung pada lahan kering dan lahan sawah disajikan pada Tabel 2.

Tabel 2.

Hasil pipilan jagung per ha

\begin{tabular}{lll}
\hline Perlakuan & \multicolumn{2}{l}{ Hasil pipilan jagung kering (t/ha) } \\
\cline { 2 - 3 } & Lahan kering & Lahan sawah \\
\hline P1 & $4,26^{\mathrm{b}}$ & $5,10^{\mathrm{b}}$ \\
P2 & $5,78^{\mathrm{a}}$ & $6,25^{\mathrm{a}}$ \\
P3 & $3,45^{\mathrm{c}}$ & $3,56^{\mathrm{c}}$ \\
\hline
\end{tabular}

Berdasarkan hasil analisis statistik terdapat pengaruh perlakuan pemupukan terhadap hasil pipilan jagung (Tabel 2). Perlakuan P2 (Urea $250 \mathrm{~kg} / \mathrm{ha}+300 \mathrm{~kg} / \mathrm{ha}$ NPK Phonska + pupuk organik 2 ton/ha di lahan sawah dan di lahan kering memberikan hasil pipilan jagung yang berbeda nyata dengan perlakuana P1 (Urea $325 \mathrm{~kg} / \mathrm{ha}+75$ $\mathrm{kg} / \mathrm{ha}$ SP-36 + $80 \mathrm{~kg} / \mathrm{ha} \mathrm{KCL}$ ) dan perlakuan P3 (100 kg/ha Urea + $200 \mathrm{~kg} / \mathrm{ha}$ NPK Phonska). Hasil pipilan jagung tertinggi ditemukan pada perlakuan P2 di lahan kering $(5,78 \mathrm{t} / \mathrm{ha})$ dan lahan sawah $(6,25 \mathrm{t} / \mathrm{ha})$, diikuti perlakuan P1 di lahan kering (4,75 t/ha) dan di lahan sawah (5,10 t/ha), dan terendah pada perlakuan P3 di lahan kering (3,45 t/ha) dan di lahan sawah (3,56 t/ha). Pengkajian di daerah Lampung menggunakan pupuk $300 \mathrm{~kg}$ Urea $+100 \mathrm{~kg} \mathrm{SP}-36+150 \mathrm{~kg} \mathrm{KCl}+5$ ton pupuk kandang diperoleh hasil jagung sebesar 5,6 t/ha (Rumbaina dan Mustikawati, 2007). Selanjutnya pengkajian di lahan kering di Sulawesi Selatan menggunakan pupuk $250 \mathrm{~kg}$ Urea + $100 \mathrm{ZA}+100 \mathrm{SP}-36+100 \mathrm{KCl}$ diperoleh hasil jagung rata-rata 4,6 t/ha (Taufik et al., 2015). Hasil penelitian varietas jagung hibrida Bima di lahan kering di 
Kabupaten Lombok Timur diperoleh hasil 6,63 t/ha ( Suriadi et al., 2014) sedangkan di Sulawesi Selatan diperoleh hasil jagung sebesar 4,5 t/ha (Taugik et al., 2015).

Hasil kajian ini menunjukkan bahwa perlakuan pemupukan berdasarkan rekomendasi Balitsereal di lahan kering dan di lahan sawah ternyata mampu meningkatkan hasil pipilan jagung petani dari 3,45-3,56 t/ha menjadi 5.78-6,25 t/ha. Berarti faktor pemupukan mempunyai peran cukup penting dalam meningkatkan hasil jagung. Pupuk jagung berdasarkan Rekomendasi Balitsereal merupakan pemupukan yang berimbang dan optimal untuk kebutuhan tanaman jagung. Penerapan pemupukan ini ditambah pupuk organik memberikan pengaruh sangat nyata dalam meningkatkan hasil jagung.

Rendahnya hasll jagung pada perlakuan

P1, pemupukan petani diduga tanaman kekurangan unsur N, P dan K. Kekurangan fosfor berpengaruh terhadap metabolisme dan pertumbuhan khususnya pembentukan tongkol dan biji sedangkan kekurangan kalium dapat menurunkan hasil jagung 10\%. Kekurangan N akan menyebabkan tanaman jagung mempunyai pertumbuhan vegetatif yang tinggi tetapi hasil panen rendah (Runcajaniningsih $e t$ al., 2013). Selanjutnya Fadwiwati dan Tahir (2013) menyatakan bahwa nitrogen merupakan hara makro yang sangat mempengaruhi pertumbuhan tanaman dan hasil jagung karena nitrogen hara esensial yang berfungsi sebagai bahan penyusun asam-asam amino, protein, dan bahan penyusun komponen inti sel. Pemupukan NPK yang cukup dan berimbang dapat meningkatkan pertumbuhan dan hasil jagung lebih tinggi seperti pada perlakuan pemupukan P2, yaitu berdasarkan Rekomendasi Balisereal.

Untuk hasil jagung optimal, selain pemberian pupuk N,P,K yang berimbang perlu ditambahkan pupuk organik/pupuk kandang $2 \mathrm{t} / \mathrm{ha}$ terutama pada tanah kandungan bahan organik rendah. Kandungan bahan organik tanah yang rendah dapat menyebabkan kesuburan tanah menjadi rendah, stabilitas agregat tanah rendah sehingga produktivitas tanah menurun. Untuk mengatasi hal tersebut, perlu dilakukan upaya rehabilitas tanah yang mampu memperbaiki lingkungan fisik dan kimia tanah sehingga sesuai untuk pertumbuhan tanaman. Salah satu alternatif memperbaiki kondisi lingkungan tanah tersebut adalah dengan pemberian bahan organik ke dalam tanah. Bahan organik tanah merupakan penyangga biologi tanah yang dapat mempertahankan penyediaan hara secara berkelanjutan untuk tanaman (Ruchjaniningsih et al., 2013). Suplai bahan organik pada lahan usahatani jagung diperlukan dari pemberian bahan organik agar kekurangan dan kerusakan sifat fisik dan kimia tanah dapat diperbaiki. Perbaikan tanah dengan memberikan bahan organik dari berbagai sumber telah dilaporkan dapat memperbaiki sifat fisik dan kimia tanah. Bahan organik mempunyai multifungsi, diantaranya adalah meningkatkan agregat tanah, meningkatkan kapasitas menahan air, meningkatkan porisitas tanah serta mempengaruhi permiabilitas dan laju infiltrasi tanah. Mempertahankan kandungan bahan organik tanah melalui pemberian pupuk kandang diharapkan mampu meningkatkan hasil jagung. Pupuk kandang sebagai bahan organik dapat meningkatkan kapasitas tukar tanah (KTK) sehingga tanah terhindar dari keracunan (Zubactirodin dan Subandi, 2008). Tanah subur memiliki sifat fisik dan kima yang optimal bagi pertumbuhan tanaman karena bahan organik berfungsi sebagai sumber hara, menunjang ketersedian hara dan kehidupan jasad renik di dalam tanah. Penambahan pupuk organik selain dapat meningkatkan kesuburan tanah juga dapat memberikan suasana yang baik bagi pertumbuhan akar, baik bobot dan panjang akar tanaman jagung sehingga dengan sistem perakaran yang baik, berpeluang bagi terserapnya unsur hara semakin besar yang berdampak pada pertumbuhan tanaman jagung yang optimal.

Tabel 3.

Usahatani jagung pada perlakuan P2 di lahan kering dan lahan sawah di Kabupaten Pandeglang, 2016

\begin{tabular}{lll}
\hline Uraian & Lahan kering & Lahan sawah \\
\hline $\begin{array}{l}\text { Total Biaya } \\
\text { Produksi }\end{array}$ & 8.500 .000 & 8.500 .000 \\
$\begin{array}{l}\text { Produksi pipilan } \\
\text { jagung }\end{array}$ & 5.780 & 6.250 \\
Harga Jual & 3.000 & 3.000 \\
Penerimaan & 17.340 .000 & $18,750.000$ \\
Keuntungan & $8,840.000$ & 10.250 .000 \\
Rasio B/C & 1,04 & 1,21 \\
\hline
\end{tabular}

Hasil analisa usaha tani jagung hibrida di lahan kering dan lahan sawah di Kabupaten Pandeglang, Banten disajikan pada Tabel 3. Dari Tabel 3 terlihat bahwa keuntungan yang 
diperoleh dari budidaya jagung di lahan kering sebesar Rp. 10.250.000 lebih besar dari pada di lahan kering sebesar Rp. 8,840.000,-

\section{KESIMPULAN}

Pemupukan pada budidaya jagung di lahan kering dan lahan sawah berdasarkan Rekomendasi Balitsereal yaitu : $250 \mathrm{~kg} / \mathrm{ha}$ Urea $+300 \mathrm{~kg} / \mathrm{ha}$ NPK Phonska +2 ton pupuk kandang/ha mampu memberikan pertumbuhan tanaman dan hasil pipilan jagung yang baik.

\section{UCAPAN TERIMAKASIH}

Terimakasih disampaikan kepada teknisi Sutirman dan Tito Raswita yang telah membantu dalam pelaksanaan pengkajian, serta kepada petani di lokasi pengkajian.

\section{DAFTAR PUSTAKA}

Adnan, A.M., Constane, R, dan Zubachtirodin. 2010. Deskripsi varietas Unggul Jagung. Balai Penelitian Tanaman Serealia

Efendi, R., Suwandi, Syarifudin dan Zubachtiroch. 2012. Penentuan takaran pupuk nitrogen pada tanaman jagung hibrida berdasarkan klorofil meter dan bagan warna daun. Jurnal Penelitian Pertanian Tanaman Panan 31 (1) : 2734.

Fadwiwati, A,Y dan A.G.Tahir 2013. Analisis faktor-faktor yang mempengaruhi produksi dan pendapatan usahatani jagung di provinsi Gorontalo. Jurnal Pengkajian dan Pengembangan Teknologi Pengkajian 16 (2) : 92-101.

Kasno, A dan T. Rostaman. 2013. Serapan hara dan peningkatan produktivitas jagung dengan aplikasi pupuk NPK Majemuk. Jurnal Penelitian Pertanian Tanaman Panan 32 (1) : 179-186
Muis, A., M.B. Pabendon, N. Nonci dan W.P.S. Waskito. 2013. Keragaman genetik Peronosclerospora maydis penyebab bulai pada jagung berdasarkan analisis marka SSR. Jurnal Penelitian Pertanian Tanaman Panan 32 (3) : 133-147

Rumbaina, D dan Mustikawati. 2007. Keragaan pertumbuhan dan hasil jagung bersari bebas di lahan masam. Jurnal Pengkajian dan Pengembangan Teknologi Pengkajian 10 (3):191-198

Ruchjaniningsih, M. Thamrin dan M. Taufik 2013. Respon varietas jagung terhadap nitogen di lahan sawah dan lahan kering. Jurnal Pengkajian dan Pengembangan Teknologi Pengkajian 16 (3):183-189,

Susanto , A.N dan M.P. Sirappa. 2005. Prospek dan strategi pengembangan jagung untuk memenuhi kebutuhan pangan di Maluku. Jurnal Litbang Pertanian 24 (2) : 70-79

Suriadi, A., B.T.R.Erawati dan M. Nazam. 2014. Produktivitas jagung komposit sprinkler sebagai pangan dan pakan di lahan kering Nusa Tenggara Barat. Jurnal Pengkajian dan Pengembangan Teknologi Pengkajian 17 (3):197-209.

Taufik, M dan M. Thamrin. 2009. Analisis input Output pemupukan beberapa varietas jagung di lahan kering. Jurnal Penelitian Pertanian Tanaman Panan 28 (2) : 78-82

Taufik, Mamtig dan Nappu. 2015. Kelayakan usahatani jagung di Sulawesi Selatan. Jurnal Pengkajian dan Pengembangan Teknologi Pengkajian 18 (1):55-66,

Zubachtiron dan Subandi. 2008. Peningkatan efisiensi pupuk N,P,K dan produktivitas jagung pada lahan kering ultisol di Kalimantan Selatan. Jurnal Penelitian Pertanian Tanaman Panan 27 (1) : 32-36 